Грищенко I. В., доктор філологічних наук, доцент, завідувач кафедри української мови Державний університет телекомунікацій (м. Київ)

\title{
ФОЛЬКЛОРНА КОМУНІКАЦІЯ ЯК МОДУС СЕМІОТИЧНОЇ СИСТЕМИ
}

Статтю присвячено дослідженню фольклору як комунікативного процесу. Розглянуто функції фольклорної комунікації як міжетнічного полілогу, запропоновано виокремити інтертекстуальну функиію. Встановлено, щзо фольклорна міжетнічна комунікачія відбувається на таких рівнях: на міжособистіному та на рівні етноспільнот. Фольклорна комунікачія є моделлю семіотичного акту і є складовою складної семіотичної системи. Фольклорна комунікачія належить до неопосередкованих, завдяки відсутності безпосереднього контактування між виконавцем та слухачами.

Ключові слова: фольклор, фольклорна комунікація, міжетнічна комунікація, інтертекстуальна функиія, семіотичний акт, система, міжетнічний полілог.

The headline of the article is "Folklore Communication as modus semiotic system". The article devotes considerable attention to folklore as communication proses. The article considers functions of folklore communication. It must be stressed that in this article author proposes to distinguish the intertextual function. It is of importance to note that folklore communication has such levels: interpersonal and interethnic community. Folklore communication is model of semiotic act and component of a complex semiotic system. Folklore communication refers to the indirect, therefore absence of contact between the performer and the listeners.

Key words: folklore, folklore communication, interethnic communication, intertextual function, semiotic act, semiotic system, interethnic polylogue.

Статью посвящено исследованию фольклора как коммуникативного прочесса. Рассмотрено функичии фольклорной коммуникации как межэтничекого полилога, предложено вылделить интертекстуальную функиию. Установлено, что фольклорная межэтническая коммуникация происходит на таких уровнях: межличностном и на уровне этносообществ. Фольклорная коммуникация является моделью семиотического акта $и$ входит в состав сложной семиотической системы. Фольклорная коммуникация принадлежст к неопосредованных, поскольку отсутствует непосредственный контакт между исполнителем и слушателями.

Ключевые слова: фольклор, фольклорная коммуникация, межэтническая коммуникация, интертекстуальная функиия, семиотический акт, система, межэтнический полилог.

Питання фольклору і комунікації, фольклорної комунікації постійно привертає науковий інтерес дослідників. У своїх дослідженнях досліджували цю проблематику, розглядали взаємодію та взаємозв’язок фольклору та комунікації такі науковці як К. Г. Робертс «Будова наративної парадигми» 
(«Texturing the narrative paradigm: Folklore and communication»), за редакцією Д. Бен-Амоса та К. С. Голдстейн було опубліковано колективну роботу «Фольклор: перфоманс і комунікація» («Folklore: performance and communication»), Л. С. Клевел «Фольклор і комунікація» (“Folklore and Communication”), «Антропологія і масова комунікація: синтез та симбіоз» («Anthropology and Mass Communication: Synthesis and Symbiosis») та ін.

В українській науці проблемі фольклорної комунікації присвячені наукові дослідження Л. Копаниці «Поетичний текст усній і книжній традиції: питання поетики та художньої семантики», «Літературний твір як модель комунікації: історична семантика драматичного панегірика Феофана Прокоповича «Володимир», О. Івановської «Суб’єктно-образна система фольклору: категоріальний аспект», Л. Омельченко та В. Самохіна «Фольклор як символічна взаємодія комунікантів», О. Гінди «Термін фольклор як понятійне та дискусійне поле», Т. Беценко «Текстово-образна універсалія як мовний засіб фольклорної комунікації» та ін. Результати досліджень засвідчують відмінність фольклорної комунікації та комунікації у літературі, мовної комунікації тощо.

Загалом акт комунікації $є$ адекватною моделлю будь-якого семіотичного акту. Тобто, це процес взаємообміну інформацією, процес спілкування, процес контактування як необхідної умови роботи тексту, середовище, в якому текст «оживає», починає виконувати свою функцію. Цінність будь-якого тексту, в свою чергу визначається його інформативністю, характер якої залежить від конкретної функції тексту у системі культури [Леута 2009:298]. Гуманітарні дисципліни послуговуються спільним понятійно-термінологічним апаратом, проте часто значення термінів і понять не співпадають у різних гуманітарних наукових галузях. Зокрема, комунікативний акт у фольклористиці визначають як природна та єдина умова маніфестації (відтворення, виконання, викладення), а відповідно - і самого існування фольклорного тексту [ТПСФ 2008]. Важливим моментом будь-якої комунікації полягає у розумінні співрозмовниками одне одного, співпадання культурних, етнічних, морально-етичних кодів, вірне тлумачення певного культурного тексту, інтерпретація отриманої інформації. 
Концепт фольклор як комунікац̧ія отримав багато теоретичного та методологічного матеріалу з соціолінгвістичної галузі. В основі лежить ідея «етнографії комунікації» Д. Хамса, яку він виклав у вступі «У напрямку до етнографії комунікації» [Бен-Амос 1975:3]. Комунікативний акт у лінгвістиці дослідники визначають як інтеракцію, процес, взаємодія між адресатом та адресантом на пересіченні осей простору i часу, результатом якого і $є$ текст (дискурс) [Бацевич 2004:67]. Т. Беценко зазначає, що обов’язковими елементами фольклорного спілкування $\epsilon$ сприйняття мовлення $\mathrm{i}$ процес слухання. Ці два різновиди мовленнєвої діяльності грунтуються на вдалому використанні мовних знань: володіння мовним кодом, і відповідно інтерпретації отриманого повідомлення [Беценко 2013:247]. Фольклорна міжетнічна комунікація відбувається на кількох рівнях: на міжособистіному та на рівні етноспільнот. Міжособистісна комунікація в ідеалі повинна бути не лише актом обміну інформації, але і засобом встановлення довірчих стосунків, розкриття особистості, досягнення взаєморозуміння. Таку взаємодію ще називають діадичною комунікацією, головною ознакою якої є спонтанність i неформальна природа спілкування, при цьому учасники отримують максимальний зворотній зв’язок [Болдонова 2009:163]. Для досягнення повноцінного міжетнічного полілогу важливе значення має прагнення зрозуміти та пізнати Інакшого, міжособистісне порозуміння представників різних етносів.

Н. Болотнова запропонувала виокремити такі основні функції фольклорної комунікації як міжетнічного полілогу: 1) презентативноінформаційна (надання культурної інформації про певний етнос, має представляти представників цього етносу у необхідному для ситуації ракурсі); 2) комунікативна (передача та отримання іноетнічної інформації, задоволення інформаційної потреби про етнічного Інакшого); 3) етнозахисна (надання відомостей, яка $є$ важливою для збереження цілісності етносу, захисту представників; надання цієї інформації регулюється приналежністю до таких категорій: етнічні Свій-Свій, етнічні Свій-Інакший, етнічні Свій-Чужий); 
4) полікодова (використання мовного та інших кодів, які входять до поняття семіотичного коду i розраховані на слухове та зорове сприйняття) [Болотнова 2015:21]. До вказаної класифікації основних функцій фольклорної комунікації як міжетнічного полілогу пропонуємо виокремити та доповнити функцію - інтертекстуальну (використання власне традиційних фольклорних текстів для відповідної реакції на події у житті та для створення новотворів), у цьому випадку також необхідне співпадання таких категорій як етнічна, гендерна, вікова тощо.

Ключові поняття виконання та спілкування дають підстави розглядати фольклор як вербальну символічну взаємодію людей. Дослідники звертають увагу таке спілкування як на пізнавально-виражально-поведінковий акт [Омельченко 2008:75]. У процесі такої взаємодії відбувається подальша ретрасляція традиційних смислів. С. Неклюдов зазначає, що до поняття «фольклорна традиція» входять мінімум чотири аспекти: «субстанційний» (визначається змістовими характеристиками - картина світу, концепти, символи, образи), «структурний» (морфологічною організацією iї текстів), «технологічний» (визначається способом комунікації - збереження, передача i відтворення повідомлень), «прагматичний» (специфікою їх функціонування) [Неклюдов 2002]. Важливими компонентами фольклорної комунікації $\epsilon$ сприйняття, декодування, розуміння, інтерпретації, тлумачення, усвідомлення отримуваної інформації та відповідної реакції на неї.

В аспекті дослідження фольклорного полілогу як комунікації - тобто взаємообміну інформацією та подальша ретрасляція уже інформації, пропущеної крізь систему власної етнокультури, науковий інтерес становлять висновки Т. Белюги. Так, дослідниця трактує освоєння інформація як взаємовплив текстових повідомлень через інтертекст. Полілог дослідниця розглядає “як своєрідний оркестр, що завдяки різним “інструментам” (вербальному, акціональному, музичному, предметному, візуальному) витворює цілісний текст [Белюга 2015:133]. 
Отже, у контексті вивчення фольклорної міжетнічної взаємодії полілог це задоволення потреби в отриманні вербалізованої та невербалізованої інформації, взаємообмін відомостями для осмислення іiі 3 позицій власного культурного рівня, життєвого досвіду та подальшого використання або ретрансляції.

Якщо раніше вагомими моментами для зацікавлення і фіксації збирачами фольклорного твору були вікова складова (представники старшого покоління як досвідчені, мудрі) і приналежність носія-етнофора до сільської спільноти, то нині отримує вагомість орієнтування у сучасній суспільно-політичній ситуації, приналежність до певної субкультури та доречне оперування фольклором. Т. Суслова доходить висновку, що сучасний фольклор $є$ особливим засобом виробництва, передачі, перероблення і збереження культурної інформації. Дослідниця вказує на протилежні тенденції, 3 одного боку, він $є$ засобом збереження i розвитку традиційної культури, a 3 іншого, проявляється байдужість до власної країни і навіть свідоме відчуження від неї і рідної мови. Дослідниця наголошує на підсиленні значення комунікативних повідомлень, гнучкості та мобільності соціальних зв’язків завдяки мережевому формату спілкування. За іiі висновками, інтернет дає можливості найшвидшого способу спілкування, формує нові інтерактивні комунікації, тобто відбувається «підйом» комунікацій засобами традиційних культурних начал [Суслова 2015:126-127]. Розгляд та аналіз сучасних творів актуального фольклору засвідчує іншу тенденцію, в умовах ведення гібридної війни українські комуніканти здійснюють акцент на любові до власної держави та поваги до мови. Саме в цьому аспекті чітко прослідковується поділ на Своїх i Чужих, у цій ситуації Інакшість відступає на задній план.

Загалом, якість соціального життя людини має пряму залежність від характеру іiі спілкування 3 іншими людьми, отримання емоційного задоволення від комунікативного процесу. Фольклорна комунікація передбачає спільність або подібність історії етносу, мови, культурний код, етнічну складову, гендерні та вікові категорії, у сучасних умовах має значення освіта та приналежність до 
певної соціальної категорії, субкультурна приналежність комунікантів. Відмінності цих характеристик або ж опозиційність зумовлює непорозуміння, несприйняття, відторгнення, сприяє сваркам.

Фольклорна комунікація $€$ неопосередкованим типом комунікації, оскільки безпосередній контакт між виконавцем фольклорного тексту та аудиторією відсутній. Хоча, звичайно, тривалий час усна форма побутування фольклору і писемність були не настільки тісно пов'язані (звичайно, про фольклоризм зараз ми не будемо говорити), саме розширення технічних можливостей для комунікації і сприяє змін у збереженні та ретрансляції фольклору. Фольклор як комунікативний процес забезпечує трансляцію етноважливої інформації за історичною вертикаллю та горизонталлю у просторі i часі, що забезпечує необхідність людини у пізнанні світу, задовольняє когнітивні потреби окремого етнофора та етнічної спільноти.

\section{БІБЛІОГРАФІЯ}

Бен-Амос 1975 - Folklore : Performance and Communication. Edited by Dan Ben-Amos and Kenneth S. Goldstain. - The Hague : Mounton Press, 1975. - 314 p.

Бацевич 2004 - Бацевич Ф. С. Основи комунікативної лінгвістики : Підручник. - К. : Видавничий центр «Академія», 2004. - 344 с.

Белюга 2015 - Белюга Т. В. Фольклорний текст : у пошуках методологічного інструментарію фольклористичного дослідження // Молодий вчений, № 10 (25). Ч. 1, жовтень, 2015. - С. 132-135.

Беценко 2013 - Беценко Т. Текстово-образна універсалія як мовний засіб фольклорної комунікації // Світогляд - Філософія - Релігія. Збірник наукових праць. - 2013 - Вип. 4. - Розділ 3. Культурологія. - С. 243-249.

Болдонова 2009 - Болдонова И. С. Герменевтика устной межличностной коммуникации // Вестник Бурятского государственного университета. Вып. № 14 / 2009. - С. 162-169 [Электронный ресурс]. - Режим доступа : http://cyberleninka.ru/article/n/germenevtika-ustnoy-mezhlichnostnoy-kommunikatsii 
Болотнова 2015 - Болотнова Н. С. Коммуникативная стилистика текста: медийные коммуникативные универсалии // Вестник ТГПУ. 9 (162). 2015.C. $19-27$.

Леута 2009 - Леута О. Н. Ю. М. Лотман о трех функциях текста // Юрий Михайлович Лотман / Под ред. В. К. Кантора. - М. : РОССПЭН, 2009. - С. $294-$ 309 [Электронный ресурс]. - Режим доступа : http://ec-dejavu.ru/1-2/Yuri_Lot man_text.html.

Неклюдов 2002 - Неклюдов С. Ю. Фольклор : типологический и коммуникативный аспекты // Традиционная культура, 2002, № 3. - С. 3-7 [Электронный ресурс]. - Режим доступа : http://www.ruthenia.ru/folklore/necklu dov67.htm

Омельченко 2008 - Омельченко Л. Ф., Самохіна В. О. Фольклор як символічна взаємодія комунікантів // Вісник Сумського державного університету. Серія Філологія. - 2008. - № 1. - С.72-76 [Електронний pecypc]. - Режим доступу: http://www.essuir.sumdu.edu.ua/handle/123456789/9577

ТПСФ 2008 - Терминология и понятия современной фольклористики : словник к круглому столу “Аппарат гуманитарных наук: сверка понятий” 12.11.2008 г. [Электронный ресурс]. - Режим доступа : http://www.gumchtenia. rggu.ru/article.html?id=72853

Суслова 2015 - Суслова Т. И. Интернет-фольклор как средство коммуникации // Журналистский ежегодник. - 2015 - С. 123-127. 